\title{
OPTIMALISASI PENDIDIKAN ISLAM DALAM MENUMBUHKAN KECERDASAN EMOSIONAL
}

\author{
Oleh: \\ Nasaruddin \\ Institut Agama Islam (IAI) Muhammadiyah Bima \\ nasarhb@gmail.com
}

\begin{abstract}
Abstrak:
Pendidikan Islam termasuk gagasan ideal pendidikan yang dapat memfasilitasi dan mendorong perekembangan seorang anak didik secara optimal baik dari unsur lahiriyah dan batiniyah. Optimalisasi pendidikan Islam dalam proses pembelajaran juga dinilai mammpu menumbukan aspek kecerdasan emosional seorang manusia/anak didik. Kecerdasan emosional dalam Islam disebut kognitif Qalbiyah karena hati merupakan pusat pendidikan akhlak. Berkenaan dengan hal tersebut, konsep kecerdasan emosional menurut pendidikan Islam sebagaimana dikemukan para pakar pendidikan Islam cenderung dipahamai sebagai perwuju sikap-sikap terpuji dari kalbu dan akal yakni sikap bersahabat, kasih sayang, empati, takut berbuat salah, keimanan, dorongan moral, bekerjasama, beradaptasi, berkomunikasi dan penuh perhatian serta kepedulian terhadap sesama mahluk ciptaan Tuhan. Secara metodologis strategi pendidikan Islam dalam menumbuhkan kecerdasan emosional menekankan domaian pentingnya peranan komponen pendidikan yang mencakup lingkungan keluarga, lingkungan sekolah, dan lingkungan masyarakat sebagai basis utama pembentukan kecerdasan emosional anak didik dalam proses pendidikan.
\end{abstract}

Kata Kunci: Optimalisasi, Pendidikan Islam, Kecerdasan, Emosional.

\section{Pendahuluan}

Dalam Islam, kecerdasan emosional dikenal dengan "Kecerdasan Qalbiyah" (Kognitif Qalbiyah). ${ }^{1}$ Dengan pendidikan hati dapat melepaskan hati dari sifat-sifat tercela, keyakinan-keyakinan syirik dan batil, berbagai penyakit psikis dan kondisi-kondisi ruhani yang rendah dan bodoh. Demikian juga jika hati manusia dididik dengan baik dan teratur, manusia

\footnotetext{
${ }^{1}$ M.Yaniyullah Delta Auliya, Melejitkan Hati dan Otak Menurut Petunjuk al-Qur'an dan Neurologi, Edisi I (Jakarta:Raja Grafindo Persada, 2005), 14
} 
akan dapat mencapai derajat Ihsan dalam beribadah kepada Allah. ${ }^{2}$ Olehnya itu syarat untuk mencerdaskan hati adalah iman. Hati adalah pusat pendidikan akhlak. Akhlak merupakan fenomena kepribadian manusia terpenting dan merupakan suatu kondisi dalam jiwa, menetap padanya dan dapat melahirkan berbagai perbuatan secara mudah serta tidak memerlukan pemikiran dan pertimbangan. ${ }^{3}$ Perbuatan-perbuatan anggota badan merupakan refleksi dari getaran-getaran hati. Karena itu, hati yang berpengetahuan dan hati yang bening, akan melahirkan perbuatan yang baik pula. Seluruh anggota badan tak mampu bertentangan dan memberontak pada hati. Karena itulah hati harus dididik, diperbaiki, diluruskan dan diberi teguran. ${ }^{4}$

Perkembangan selanjutnya, kecerdasan emosional mengalami perkembangan baru dan secara umum menggambarkan sebagai potensi psikologis yang bersifat positif dan perlu dikembangkan. Daniel Goleman misalnya mengatakan bahwa kecerdasan emosional mengandung beberapa pengertian. Pertama, kecerdasan emosi tidak hanya berarti bersifat ramah, pada saat-saat tertentu yang diperlakukan mungkin bukan sikap ramah, melainkan sikap tegas yang barangkali memang tidak menyenangkan, tetapi mengungkapkan kebenaran yang selama ini dihindari. Kedua, kecerdasan emosi bukan berarti memberikan kebebasan kepada perasaan untuk berkuasa memanjakan perasaan, melainkan mengelola perasaan sehingga terekspresikan secara tepat dan efektif yang memungkinkan orang bekerjasama dengan lancar menuju sasaran bersama. Kecerdasan emosional lebih lanjut dapat diartikan kepiawaian, kepandaian dan ketepatan seseorang dalam mengelola diri sendiri dalam berhubungan dengan orang lain di sekeliling mereka dengan menggunakan seluruh potensi psikologis yang dimilikinya seperti inisiatif, empati, adaptasi, komunikasi, kerjasama dan kemampuan persuasi yang secara keseluruhan telah mempribadi kepada diri seseorang. 5

\footnotetext{
${ }^{2}$ M.Yaniyullah Delta Auliya, Melejitkan Hati dan Otak...,17.

${ }^{3}$ Ahmad Mahmud Subhi, al-Falsafah al-Ahklāqiyah fi al-Fikri al-Islām (Mesir:Dar al-Ma'arif, t.th), 263.

${ }^{4}$ M.Yaniyullah Delta Auliya, Melejitkan Hati dan Otak.., 16.

${ }^{5}$ Daniel Goleman, Emotional Intelligence (Cet. I ; New York :Bantam Books, 1995), 9.
} 
Untuk menggambarkan adanya kecerdasan emosional pada diri manusia, al-Qur'an lebih menginformasikan adanya unsur nafs, qalb, ruh dan aql. Kata nafs dalam al-Qur'an mempunyai aneka makna, terkadang diartikan totalitas manusia, dan terkadang diartikan sebagai apa saja yang terdapat dalam diri manusia yang menghasilkan tingkah laku. Sedangkan qalb dalam al-Qur'an digambarkan sebagai wadah bagi pengajaran, kasih sayang, takut dan keimanan. Dengan demikian qalbu menampung hal-hal yang didasari pemiliknya. Wadah kalbu ini dapat diperbesar, diperkecil atau dipersempit. Ia dapat diperlebar dengan amal-amal kebajikan serta oleh jiwa. Selanjutnya qalbu sebagai alat dilukiskan pula dengan kata $F$ ' $^{\prime}{ }^{\prime}{ }^{6}{ }^{6}$ Dengan demikian kecerdasan emosional yang dimaksud dalam tulisan ini adalah, kemampuan seseorang untuk mendengarkan hati nuraninya atau bisikan yang meng-Ilahi dalam diri seseorang, mengambil keputusan atau melakukan pilihan-pilihan dalam setiap tindakan yang akan dilakukannya, agar tindakan yang dilakukannya tersebut sejalan dengan keinginan hatinya, yang pada akhirnya melahirkan akhlak yang mulia. Jadi berbicara masalah kecerdasan emosional maka terlebih dahulu kita harus berbicara kecerdasan spiritual, olehnya itu sebelum membina EQ maka yang perlu dibina terlebih dahulu adalah spiritual, karena kecerdasan spiritual sebagai tonggak utama berhasilnya kecerdasan-kecerdasan yang lain.

\section{Konsep Kecerdasan Emosional Menurut Pendidikan Islam}

Konsep Kecerdasan Emosional sebagaimana digambarkan pada uraian sebelumnya, terkait dengan sikap-sikap terpuji dari kalbu dan akal yakni sikap bersahabat, kasih sayang, empati, takut berbuat salah, keimanan, dorongan moral, bekerjasama, beradaptasi, berkomunikasi dan penuh perhatian serta kepedulian terhadap sesama mahluk ciptaan Tuhan. ${ }^{7}$ Adapun ciri yang menandai kecerdasan emosional dalam pendidikan Islam terdapat pada pendidikan akhlak. ${ }^{8}$ Para pakar pendidikan Islam dengan berbagai ungkapan, pada umumnya sepakat bahwa tujuan pendidikan Islam adalah membina pribadi muslim yang sempurna dan beribadah kepada Allah swt.

\footnotetext{
${ }^{6}$ Abuddin Nata, Manajemen Pendidikan (Bogor ; Kencana, 2003), 46.

${ }^{7}$ Abuddin Nata, Manajemen Pendidikan (Bogor; Kencana, 2003), 45.

${ }^{8}$ Secara terminology akhlak menurut Imam al-Ghazali ialah sifat yang tertanam dalamjiwa yang menimbulkan perbuatan-perbuatan dengan mudah, tanpa melakukan pemikiran dan pertimbangan. Lihat Abu Hamid Muhammad al-Ghazali, Ihya Ulum al-Din, Jilid.III (Beirut:Dar al-Fikr, 1989), 58.
} 
termasuk salah satunya adalah akhlak mulia. Al-Akhlāk al-karīmah dalam Islam adalah hal yang berhubungan dengan kecakapan emosi dan spiritual seperti konsistensi (Istiqāmah), rendah hati (tawādu), berusaha keras (Tawākkal), ketulusan (Ikhlās), Totalitas (Käffah), Keseimbangan (tawāzun), integritas dan penyempurnaan (Ihsān). ${ }^{9}$

Kecerdasan emosional dalam Islam disebut kognitif Qalbiyah karena hati merupakan pusat pendidikan akhlak, ${ }^{10}$ sebagaimana uraian pada bab sebelumnya. Olehnya itu hati harus dididik, diperbaiki, diluruskan, diberi perhitungan dan diberi teguran. Pendidikan dan pelurusan hati bertujuan memunculkan kecerdasan yang dimilikinya atau untuk mengobati penyakitpenyakit psikis yang diderita. Dengan dididik dan diluruskan, hati akan dapat menggapai kondisi-kondisi ruhani yang positif dan sifat-sifat kesempurnaan. ${ }^{11}$ Para pakar pendidikan telah mengemukakan bahwa pendidikan Islam di samping berupaya membina kecerdasan intelektual, keterampilan dan raganya, juga membina jiwa dan hati nuraninya. ${ }^{12}$

Berarti secara umum pendidikan Islam membina IQ, EQ, pendidikan Islam juga membina aspek spiritual (SQ) karena kecerdasan spiritual adalah landasan memfungsikan kecerdasan intelektual (IQ) dan kecerdasan emosional (EQ) secara efektif, IQ tidak mengukur kreativitas, kapasitas emosi, nuansa spiritual dan hubungan sosial, sedangkan kecerdasan qalbiyah (Kognitif Qalbiyah) apabila telah mendominasi jiwa manusia maka akan menimbulkan kepribadian yang tenang. Secara jasmaniah berkedudukan di jantung, daya yang dominan adalah emosi (rasa) atau afektif, mengikuti natur roh (Ilāhiyah), potensinya bersifat zauqīyah dan hadsiah yang sifatnya spiritual, intinya religiusitas, spritualitas dan transendensi yang akhirnya melahirkan kecerdasan emosional. ${ }^{13}$ Tandatanda Kecerdasan Spiritual berkembang dengan baik adalah sebagai berikut; kemampuan bersikap fleksibilitas, tingkat kesadaran diri yang tinggi, kemampuan memanfaatkan penderitaan, kemampuan melawan rasa

\footnotetext{
${ }^{9}$ Ary Ginanjar Agustian, ESQ The ESQ Way 165 (Jakarta:Arga, 2005), 280.

${ }^{10}$ M.Yaniyullah Delta Auliya, Melejitkan Hati dan Otak Menurut Petunjuk alQur'an dan Neurologi, Edisi I (Jakarta:Raja Grafindo Persada, 2005), 14.

${ }^{11}$ M.Yaniyullah Delta Auliya, Melejitkan Hati dan Otak ...,17.

${ }^{12}$ Abdul Mujib dan Yusuf Mudzakkir, Ilmu Pendidikan Islam (Cet.I; Yogyakarta:Graha Ilmu, 2007), 139.

${ }^{13}$ Lihat, M.Yaniyullah Delta Auliya, 14-15.
} 
sakit, kualitas hidup yang diilhami oleh visi dan nilai-nilai, keengganan menyebabkan kerugian yang tidak perlu, kemampuan melihat keterkaitan segala hal, selalu bertanya mengapa? atau bagaimana? Untuk mencari jawaban yang mendasar dan kemandirian dalam berpikir. ${ }^{14}$

Pada prinsipnya kita harus sadar bahwa; "setiap manusia memiliki segudang kecerdasan, tetapi jika tidak dibarengi dengan kecerdasan spiritual, jiwa manusia tidak akan merasakan kebahagiaan. Sebagaimana Toto Tasmara mengemukakan bahwa betapapun banyak kecerdasan yang dimiliki seseorang tetapi tidak dibarengi dengan kecerdasan spiritual maka dengan sendirinya kecerdasan yang lain tersebut tidak akan berguna sama sekali. ${ }^{15}$ Hal tersebut senada dengan pandangan Ary Ginanjar bahwa kecerdasan emosional dan spiritual semestinya tidak boleh dipisahkan karena kecerdasan emosional yang tidak dibarengi kecerdasan spiritual akan menyebabkan manusia menjadi sesat dan spekulatif. ${ }^{16}$ Oleh karenanya mengabaikan potensi kecerdasan spiritual pada anak akan membawa masalah di kemudian hari. Kecerdasan spiritual yang dimaksud di sini, bukan berarti anak tersebut mampu melakukan ritual keagamaan dengan baik, tetapi anak percaya akan adanya kekuatan nonfisik yang lebih dari kekuatan diri manusia. Sebuah kesadaran yang menghubungkan manusia dengan Tuhan lewat hati nurani. Kecerdasan spiritual jangan hanya mampu melaksanakan ritus-ritus keagamaan tetapi yang lebih penting adalah pemahaman terhadap nilai-nilai ritualisme tersebut. ${ }^{17}$ Sebagai contoh kesalah pahaman tentang kecerdasan spiritual hanya berhenti pada ritus adalah fenomena krisis kemanusiaan yang melanda bangsa Indonesia yang mayoritas berpenduduk muslim. Bangsa yang kelihatan sangat agamis, justru terkenal tindak kriminalnya, lebih menyedihkan lagi di tengah semaraknya aktivitas formal keagamaan, sering dipertontonkan prilakuprilaku brutal seperti pembakaran tempat ibadah, perusakan rumah orang yang tak seagama, saling menjelek-jelekkan satu agama dengan lainnya yang sering berakhir dengan konflik dan peperangan. ${ }^{18}$

\footnotetext{
${ }^{14}$ Syamsul Ma'arif, Revitalisasi Pendidikan Islam, Edisi I (Yogyakarta:Graha Ilmu, 2007), 139.

${ }^{15}$ Toto Tasmara, Kecerdasan Ruhaniah (Cet.I; Jakarta: Gema Insani Press, 2001), 49

${ }^{16}$ Ary Ginanjar Agustian, ESQ The ESQ Way 165..., 47.

${ }^{17}$ Syamsul Ma'arif, Revitalisasi Pendidikan Islam ...,139.

${ }^{18}$ Syamsul Ma'arif, Revitalisasi Pendidikan Islam...,142.
} 
Pendidikan Islam dalam pertumbuhan spiritual dan moral, harus mampu menolong individu menguatkan iman, akidah, dan pengetahuan terhadap Tuhannya dengan hukum-hukum, ajaran-ajaran dan moral agamanya. Pendidikan spiritual atau sering disebut al-Tarbiyah al-Rūhīyah, yang memiliki dimensi kemanusiaan harus ditekankan dalam pendidikan Islam. Mengingat peran penting spiritual ini bagi kehidupan, pendirian suatu pendidikan Islam pun harus didasarkan pada falsafi bahwa pendidikan adalah proses menuju kesempurnaan. Fungsi agama (iman) yang ditumbuhkan sejak kecil, dan menyatu ke dalam kepribadian itulah yang membawa ketentraman batin dan kebahagiaan. Orang yang mempercayai benda-benda keramat, jimat dan sebagainya biasanya tenang selama benda tersebut ada padanya. Akan tetapi jika benda keramat itu hilang maka yang bersangkutan akan gelisah. Obyek keimanan yang tidak pernah hilang dan tidakakan berubah manfaatnya, adalah iman yang ditentukan oleh agama. Iman yang berlandaskan agama akan selalu mendatangkan ketentraman. Islam mengajarkan 6 pokok keimanan (rukun iman) yang diproyeksikan dalam pengalaman dan kehidupan sehari-hari dengan pelaksanaannya berpedoman kepada pokok-pokok ajaran Islam (rukun Islam). ${ }^{19}$ Hal tersebut sejalan dengan pandangan Ary Ginanjar bahwa untuk membangun kecerdasan emosional maka sebelumnya kita harus mendalami terlebih dahulu nilai-nilai yang terdapat dalam rukun Iman lalu mengaplikasikannya dengan nilai yang terdapat dalam rukun Islam.

\section{Strategi Pendidikan Islam dalam Menumbuhkan Kecerdasan Emosional}

Strategi menurut Muhaimin adalah langkah-langkah yang disusun secara terencana dan sistematis dengan menggunakan metode dan teknik tertentu. ${ }^{20}$ Strategi mengandung pengertian rangkaian prilaku pendidikan yang tersusun secara terencana dan sistematis untuk mentransformasikan dan menginternalisasikan nilai-nilai moral Islami agar dapat membentuk kepribadian anak secara utuh. Strategi pendidikan pada hakekatnya adalah pengetahuan atau seni mendayagunakan semua faktor/kekuatan untuk mengamankan sasaran kependidikan yang hendak dicapai melalui

${ }^{19}$ Zakiah Daradjat, Pendidikan Islam dalam Keluarga dan Sekolah (Cet.II;Jakarta:Ruhama, 1995), 9

${ }^{20}$ Muhaimin, Ilmu Pendidikan Islam suatu Tinjauan Teoritis dan Praktis Berdasarkan Pendekatan Interdisipliner (Cet.V ;Jakarta :Bumi Aksara, 2000), 58. 
perencanaan dan pengarahan dalam operasionalisasi sesuai dengan situasi dan kondisi lapangan yang ada, termasuk pula perhitungan tentang hambatan-hambatannya baik berupa fisik maupun yang bersifat non-fisik (seperti mental spiritual dan moral baik dari subyek, obyek maupun lingkungan sekitar). Adapun strategi pendidikan Islam dalam upaya menumbuhkan kecerdasan emosional menjadi tanggung jawab:

\section{Lingkungan keluarga}

Keluarga merupakan lingkungan pertama dan utama bagi anak. Oleh karena kedudukan keluarga dalam pengembangan kepribadian anak sangatlah dominan. Dalam hal ini orangtua mempunyai peranan yang sangat penting dalam menumbuhkembangkan fitrah keberagamaan anak. Menurut Hurlock keluarga merupakan "Training Centre" bagi penanaman nilai-nilai pengembangan fitrah atau jiwa beragama anak seyogyanya bersamaan dengan perkembangan kepribadiannya yaitu sejak lahir bahkan lebih dari itu sejak dalam kandungan. ${ }^{21}$ Upaya menanamkan keimanan dan mengembangkan fitrah anak dalam lingkungan keluarga sebagai berikut :

a. Tahap asuhan (usia 0-2 tahun), yang lazim disebut fase neonatus, dimulai kelahiran sampai kira-kira dua tahun

Pada tahap ini, individu belum memiliki kesadaran dan daya intelektual, ia hanya mampu menerima ransangan yang bersifat biologis dan psikologis melalui air susu ibunya. Pada fase ini belum dapat diterapkan interaksi edukasi secara langsung, karena itu proses edukasi dapat dilakukan dengan cara :

1) Mengazankan di telinga kanan dan iqamah di telinga kiri ketika baru lahir. Azan dan iqamah ibarat password untuk membuka sistem syaraf rohani agar anak teringat dengan apa yang dulu di alam arwah diberi perjanjian oleh Allah swt; Hal tersebut relevan dengan sabda Rasulullah saw. Inc), 21.

${ }^{21}$ Hurlock Elizabeth, Child Development (New York:Mc. Graw Hill Book Company 


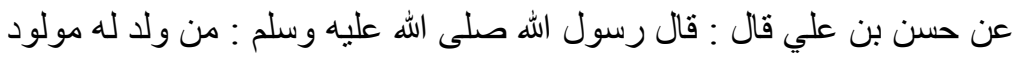

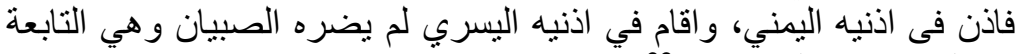

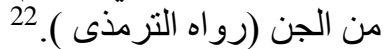

Artinya :

Dari Hasan bin Ali ra, Dia berkata : Rasulullah saw. bersabda : "Barangsiapa lahir bayinya seorang anak, maka hendaklah ia membacakan adzan pada telinga kanannya, dan iqamah pada telinga yang sebelum kiri, niscaya ia tidak akan diganggu oleh jin". 23

2) Akikah, dua kambing untuk bayi laki-laki dan seekor kambing untuk bayi perempuan. Pemotongan ini, selain menunjukkan rasa syukur kepada Allah, juga sebagai lambang atau symbol pengorbanan dan kepedulian sang orang tua terhadap kelahiran bayinya, agar anaknya nanti menjadi anak saleh dan menuruti keinginan baik orang tuanya;

أخرجه البيهقى عن عبد الله بن يزيد عن أبيه عن النبى صلى الله عليه وسلم. انه قال : العقيقة تنبخ لسبع او الابع عشرة او احدى و عشرين. (رواه ابو البه داود)

Artinya :

Diungkapkan oleh Baihaqi dari Abdullah bin Yazid dari bapaknya yang bersumber dari Rasululllah saw, sesuai sabdanya : "Aqiqah itu penyembelihannya pada hari ketujuh atau keempat belas atau hari kedua puluh satu dari kelahiran anak. ${ }^{25}$

3) Memberi nama yang baik, yaitu nama yang secara psikologis mengingatkan atau berkorelasi dengan perilaku yang baik, misalnya nama al-Asmā' al-Husnā, nama-nama Nabi, nama-nama sahabat, nama-nama orang saleh, dan sebagainya;

4) Membiasakan hidup yang bersih, suci dan sehat;

5) Memberi ASI sampai usia dua tahun. ASI selain memiliki komposisi gizi yang sesuai dengan kebutuhan bayi, juga menambah keakraban, kehangatan, dan kasih sayang sang

\footnotetext{
${ }^{22}$ Al- Tirmidzi, Sunan al-Tirmizi, Kitab al-Adahiy, Bab al-Azan Fī Uzūn al-Maulud (Lebanon: Dar al-Fikr, 1414 H), 173.

${ }^{23}$ Abdullah Nashih Ulwan, Tarbiyatu al-Awlad fi al-Islam (Cet. II; Beirut: Dar alSalam , 1978), h. 150.

${ }^{24}$ Al-Imam al-Hafiz Abi Dawud, op. cit., 259.

${ }^{25}$ Terjemahan Penulis
} 
ibu dengan bayinya atau sebaliknya. Sebagaimana firman Allah swt. dalam QS. al-Baqarah (2): 233.

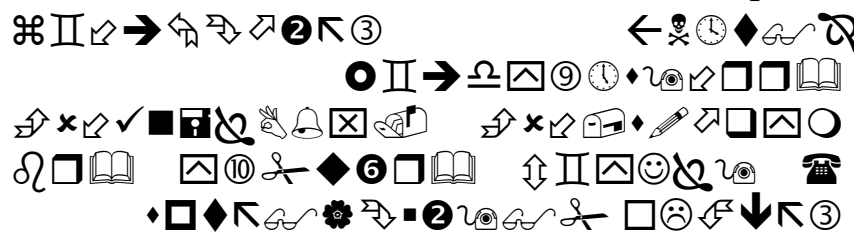

Terjemahnya :

233) Para ibu hendaklah menyusukan anak-anaknya selama dua tahun penuh, yaitu bagi yang ingin menyempurnakan penyusuan. ${ }^{26}$

6) Memberi makanan dan minuman yang halal dan bergizi (thayyib), QS. al-Baqarah (2):168

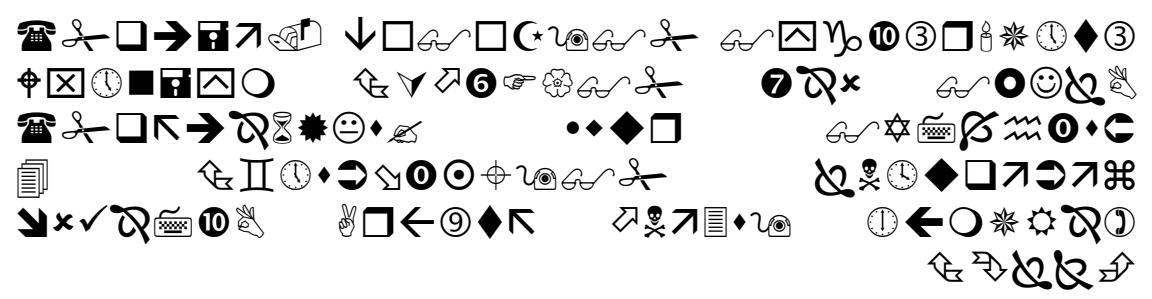

Terjemahnya :

168). Hai sekalian manusia, makanlah yang halal lagi baik dari apa yang terdapat di bumi, dan janganlah kamu mengikuti langkah-langkah syaitan; Karena Sesungguhnya syaitan itu adalah musuh yang nyata bagimu. ${ }^{27}$

b. Tahap pendidikan jasmani dan pelatihan pancaindra (usia 3-12 tahun), yang lazim disebut fase kanak-kanak (al-thifl/shabi), yaitu mulai masa neonatus sampai pada masa polusi (mimpi basah).

Pada tahap ini, anak mulai memiliki potensi-potensi biologis, paedagogis, dan psikologis. Karena itu, pada tahap ini mulai diperlukan adanya pembinaan, pelatihan, bimbingan, pengajaran, dan pendidikan yang disesuaikan dengan bakat, minat dan kemampuannya. Proses pembinaan dan pelatihan lebih efektif lagi bagi anak telah menginjak usia sekolah dasar. Hal tersebut karena pada fase ini, anak mulai aktif dan memfungsikan potensi-potensi 1971), 67.

${ }^{26}$ Departemen Agama, al-Qur'an dan Terjemahnya (Cet.I;Jakarta:Cipta Adi Pustaka,

${ }^{27}$ Departemen Agama, al-Qur'an dan Terjemahnya..., 46. 
indranya walaupun masih pada taraf pemula. Proses edukasi dapat diterapkan dengan penuh kasih sayang. Perintah dan larangan disajikan dalam bentuk cerita-cerita yang menarik dan memberikan kesimpulan untuknya, serta melatih anak untuk melakukan aktivitas positif yang dapat membiasakan dirinya dengan baik bila kelak menginjak fase berikutnya.

Tugas pendidikan pada fase ini adalah menumbuhkan potensi-potensi indra dan psikologis, seperti pendengaran, penglihatan, dan hati nurani. Tugas orang tua adalah bagaimana mampu merangsang pertumbuhan berbagai potensi tersebut, agar anaknya mampu berkembang secara maksimal. Firman Allah swt.: "Dan Allah mengeluarkan kalian dari perut ibu kalian dalam keadaan tidak mengetahui apa-apa. Dan Ia memberikan pendengaran, penglihatan, dan hati sanubari agar kamu mau bersyukur."

Mempersiapkan diri dengan cara membiasakan dan melatih hidup yang baik, seperti dalam berbicara, makan, bergaul, penyesuaian diri dengan lingkungan, dan berperilaku. Pembiasaan ini terutama pada aspek-aspek efektif, sebab jika aspek ini tidak dibiasakan sedini mungkin maka ketika masa dewasanya akan sulit dilakukan; dan pengenalan aspek-aspek doktrinal agama, terutama yang berkaitan dengan pengimanan, melalui metode cerita dan uswah al-hasanah.

c. Tahap pembentukan watak dan pendidikan agama (usia 12-20 tahun). Fase ini lazimnya disebut fase tamyiz, yaitu fase di mana anak mulai mampu membedakan yang baik dan yang buruk, yang benar dan yang salah. Atau, fase baligh (disebut juga mukallaf) di mana ia telah sampai berkewajiban memikul beban taklif dari Allah swt. Usia ini anak telah memiliki kesadaran penuh akan dirinya, sehingga ia diberi beban tanggung jawab (taklif), terutama tanggung jawab agama dan sosial.

Praktik formal syariah dimuali pada usia tamyiz, yaitu dari usia tujuh sampai kira-kira usia lima belas tahun. Pada usia ini orangtua dianjurkan menggunakan persuasi (paksaan verbal), 
tetapi antara usia sepuluh sampai lima belas paksaan fisik telah dianjurkan. ${ }^{28}$

d. Tahap kematangan (usia 20-30 tahun).

Pada tahap ini, anak telah beranjak menjadi dewasa, yaitu dewasa dalam arti sebenarnya, mencakup kedewasaan biologis, sosial, psikologis dan kedewasaan religius. Proses edukasi dapat dilakukan dengan memberi pertimbangan dalam menentukan teman hidupnya yang memiliki ciri mukafaah dalam aspek agama, ekonomi, sosial dan sebagainya.

e. Tahap kebijaksanaan (usia 30 meninggal).

Menjelang meninggal, fase ini lazimnya disebut fase azm al-'umr (lanjut usia) atau syuyūkh (tua). Proses edukasi bisa dilakukan dengan mengingatkan agar mereka berkenan sedekah atau zakat bila ia lupa serta mengingatkan agar harta dan anak yang dimiliki selalu didarmabaktikan kepada agama, negara, dan masyarakat sebelum menjelang hayatnya.

Demikianlah tahap-tahap perkembangan manusia dalam upaya menanamkan rasa kesadaran beragama dan rasa keberimanan sebagaimana dalam firman Allah swt. QS. alMu'min (40): 67

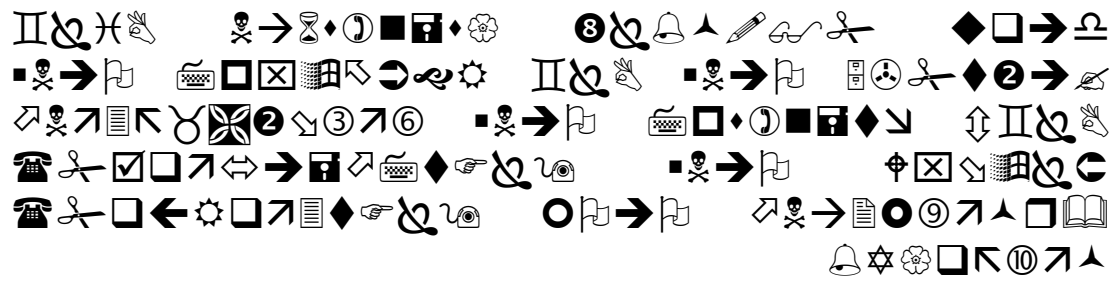

Terjemahnya :

67. Dia-lah yang menciptakan kamu dari tanah Kemudian dari setetes mani, sesudah itu dari segumpal darah, Kemudian dilahirkannya kamu sebagai seorang anak, Kemudian (kamu dibiarkan hidup) supaya kamu sampai kepada masa (dewasa), Kemudian (dibiarkan kamu hidup lagi) sampai tua, di antara kamu ada yang diwafatkan sebelum itu. (Kami perbuat

${ }^{28}$ Lihat Yasien Mohamed, Insan yang Suci,Konsep Fitrah dalam Islam (Cet.I;Bandung:Mizan, 1997), 133. 
demikian) supaya kamu sampai kepada ajal yang ditentukan dan supaya kamu memahami(nya). ${ }^{29}$

Pendidikan keimanan kepada anak telah dijelaskan oleh Allah swt. dalam al-Qur'an Surah Luqman yang dapat dijadikan contoh dalam mendidik anak yaitu :.

a. Pendidikan ketauhidan agar ber-Tuhan pada Allah Yang Maha Esa mencakup :

1) Mensyukuri nikmat

2) Meyakini pembalasan

3) Melarang keras syirik

b. Pendidikan akhlak agar anak memiliki akhlak terpuji

1) Akhlak kepada orangtua

2) Akhlak kepada masyarakat

c. Pendidikan shalat artinya anak-anak harus mengerjakan shalat sebagai salah satu tanda kepatuhan kepada Allah swt.

d. Pendidikan amar ma'ruf nahi munkar artinya anakharus bersifat konstruktif bagi perbaikan kehidupan masyarakat.

e. Pendidikan ketabahan dan kesabaran. ${ }^{30}$

Dari kelima materi pendidikan yang diberikan Luqman di atas dalam hal ini orangtua dapat menjadikannya sebagai contoh teladan dalam mendidik anaknya. Hal ini sangat menunjang dalam upaya menanamkan keimanan pada diri anak. Adapun upaya-upaya lain yang menunjang pembinaan keagamaan kepada anak yaitu :

a. Menjadikan kehidupan rumah tangga menjadi kehidupan muslim dalam segala hal seperti membiasakan anak shalat, puasa, zikir, doa makan, berpakaian sebelum memahamai benar maknanya.

b. Sejak kecil anak dibiasakan ke masjid untuk shalat dan mengikuti pengajian. Hal ini akan masuk dalam jiwanya tanpa melalui proses berpikir. Memerintahkan anak shalat ketika berumur 7 tahun dan ketika berumur 10 tahun memisahkan tempat tidurnya.

c. Pada saat libur sekolah, anak diikutkan pesantren kilat. ${ }^{31}$

${ }^{29}$ Departemen Agama, al-Qur'an dan Terjemahnya...,758.

${ }^{30}$ Ahmad Tafsir, Ilmu Pendidikan dalamPersfektif islam (Cet.I;Bandung:Remaja Rosda Karya, 1991), 189. 


\section{Lingkungan Sekolah}

Sekolah merupakan lembaga pendidikan formal yang mempunyai program yang sistematis dalam melaksanakan bimbingan pengajaran dan latihan kepada anak (siswa) agar mereka berkembang sesuai dengan potensinya. Metode yang digunakan oleh Ary dalam membangun ESQ yaitu nilai-nilai keimanan dan aplikasinya adalah nilai-nilai keislaman sebenarnya sejalan dengan fondasi utama pendidikan Islam yaitu iman, karena dengan menguatkan keimanan pada diri anak maka perilaku anak tersebut akan berlangsung berdasarkan pikiran yang telah dibenarkan dan diyakini oleh kalbunya.

Pola pendidikan Islam sudah saatnya berorientasi pada tujuan memudahkan untuk memahami nilai-nilai universal dengan pendekatan agama yang dipeluk dan mengingatkan kita bahwa agama Islam sebenarnya telah mengajarkan nilai-nilai yang sejalan dengan nilai-nilai universal dan modern tersebut sejak 14 abad yang lalu. Dengan visi dan orientasi ini, tujuan pendidikan masa depan setidaknya diarahkan pada dua sasaran yaitu :

a. Learning to think (belajar bagaimana berpikir); atau learning to know. Berpikir terus menerus bukan hal yang mudah.Termasuk di sini adalah sasaran agar berpikir secara rasional, tidak sematamata mengikuti atau "membeo", bahkan juga tidak mandeg atau tumpul. Bukankah banyak ayat al-Qur'an mengajarkan untuk berpikir dan belajar, baik menggunakan istilah berpikir maupun tantangan secara langsung. Ungkapan afalā ta'qilūn (apakah kamu tidak menggunakan akal/berpikir? Sebagai ungkapan teguran dari Allah kita jumpai dalam al-Qur'an tidak hanya sekali. Al-Qur'an juga menyebutkan bahwa salah satu ciri ulu al$b \bar{a} b$ adalah mereka yang bepikir tentang penciptaan langit dan bumi. Lebih dari sekedar teguran dan suruhan untuk berpikir, tidak sedikit ayat yang berupa tantangan berpikir secara riil. Keingin tahuan menjadi sangat penting dalam hidup, dan hal ini baru dapat terwujud jika kita mampu selalu berpikir. Dalam

${ }^{31}$ Jalaluddin, Mempersiapkan Anak Saleh (Telaah Pendidikan terhadap Sunnah Rasulullah Saw) (Cet.III; Jakarta:Raja Grafindo Persada, 2002), 127. 
tradisi Islam termasuk syarat untuk dapat memperoleh ilmu adalah zakā' dan hirsh.

b. Learning to do (belajar hidup atau belajar bagaimana berbuat/bekerja). Pendidikan dituntut untuk menjadikan anak didik setelah selesai mampu berbuat dan sekaligus mampu memperbaiki kualitas hidupnya, sesuai dengan tantangan yang ada. Agama Islam menyebutkan perintah Allah kepada hambanya agar beramal salih. Lebih dari itu, ada juga tantangan Allah kepada manusia agar mengelola bumi seisinya. Di samping kemampuan (skill) sangat diperlukan, ketekunan, kerja keras, tanggung jawab, disiplin dan semacamnya juga sangat diperlukan untuk mampu berkompetensi secara ketat.

c. Learning to be (belajar bagaimana tetap hidup; atau sebagai dirinya). Untuk dapat tetap hidup diperlukan pula "tahu diri". Dalam bahasa agama, hal ini akan menghasilkan sikap tahu diri, sikap memahami dirinya sendiri, sadar kemampuan diri sendiri dan nantinya akan mampu menjadikan dirinya mandiri. Dengan demikian seseorang yang telah menjalankan hal ini akan terhindar dari sikap dengki, hasud, serakah dan perilaku tercela.

d. Learning to live together (belajar untuk hidup bersama-sama). Ini merupakan dunia kenyataan; pluralisme. Hal ini dapat terwujud jika kita bersedia menerima kenyataan adanya perbedaan. Abad 21 adalah abad global sekaligus plural, terdiri dari berbagai macam etnis, suku, agama, budaya dan bermacam-macam perbedaan. Oleh karena itu, cara yang harus dipilih adalah kesanggupan untuk belajar hidup berdampingan bersama-sama, tanpa harus uniformity. Islam dengan jelas telah mengajarkan realitas perbedaan agama ini dengan sederhana dan tegas lakum dīnukum waliya dīn. Islam juga mengajarkan perlunya saling mengenal dan saling belajar serta saling memanfaatkan atau membantu satu sama lain. ${ }^{32}$

Muatan kurikulum dewasa ini yang lebih banyak menekankan pada aspek hafalan, harus segera diformulasi ulang

${ }^{32}$ Tohirin, Psikologi Pembelajaran Pendidikan Agama Islam, Edisi I (Jakarta:Raja Garfindo Persada, 2006), 84-85. 
dengan lebih menekankan pada aspek yang merangsang dinamika intelektual, tanpa melupakan aspek moral. Hal ini bukan berarti bahwa aspek hafalan tidak diperlukan sama sekali tetapi muatan yang demikian hendaknya diminimalkan. Olehnya itu, kurikulum harus bersifat proporsional-dinamis, dengan memperhatikan beberapa prinsip yaitu : Pertama, Prinsip filosofis; muatan kurikulm harus mampu mencerminkan pesan moral nilai keilmiahan yang bernuansa religius. Kedua, Prinsip integralistik psikologis Ketiga, prinsip sosiologis Keempat cakupan materi kurikulum hendaklah selaras dengan fitrah insani, yang meliputi aspek psikis, fisik, sosial, budaya maupun intelektual. Kelima bentuk kurikulum yang ditawarkan bersifat realistic dan operasionalistik (dapat dilaksanakan sesuai dengan kemampuan dan situasi peserta didik) serta bersifat efektif dan efisien bagi kehidupannya.

Pelajaran agama sebaiknya diikuti dengan praktek langsung dan metode berdasarkan pembinaan rasa keimanan. Misalnya shalat, zakat, puasa, infaq dan lain-lain, bukan hanya hafalan dan verbalisme. Ajaran Islam yang bermuatan etika sosial seperti kesucian dan kebersihan sebaiknya tidak untuk dihafal, tetapi harus dipraktekkan dalam keseharian. Demikian pula ajaran tentang ketepatan waktu, tanggung jawab, menepati janji, hal-hal yang berkaitan dengan hak-hak orang lain harusnya menjadi diskursus dalam pelajaran agama. Ada banyak cara yang dapat ditempuh dalam rangka pemupukan nilai-nilai agama, antara lain;

1. Untuk mengajarkan surat al-Ma'un anak diajak mengunjungi panti asuhan, panti anak yatim sekaligus diberi penjelasan yang cukup diikuti dengan praktek

2. Sejarah dan cerita (kisah-kisah dalam al-Qur'an, sahabat, ulama) merupakan cara yang cukup efektif dalam membentuk kepribadian.

3. Perwujudan dalam praktek. Pelajaran shalat harus dipraktekkan. Demikian pula zakat, infak puasa, di samping perlu uraian makna dibalik praktek, bukan semata-mata penekanan ajaran wajib 
4. Ada penekanan pada kehidupan sosial. Oleh karena itu, ajaran Islam tentang etika sosial sangat terabaikan dalam pendidikan agama. Islam sebenarnya untuk kehidupan di dunia, sedang akhirat merupakan konsekuensi dan akibat dari amal di dunia. 33

Selanjutnya adalah guru. Langkah yang harus dilakukannya adalah meningkatkan kecerdasan emosionalnya sendiri, dan dalam waktu yang sama berusaha meningkatkan kecerdasan emosional murid-muridnya. Baik guru maupun murid dapat memanfaatkan proses pembelajaran guna meningkatkan kecerdasan emosional mereka. Dengan demikian, proses pembelajaran akan sangat menyenangkan karena dibangun di atas sikap saling menghargai dan menjawab kebutuhan masingmasing.

Dalam melaksanakan tugas tersebut maka guru dituntut memiliki karakteristik:

a. Kepribadian yang mantap (akhlak yang mulia)

b. Menguasai disiplin ilmu dalam bidang studi pendidikan agama Islam.

c. Memahami ilmu-ilmu yang lain yang relevan atau menunjang kemampuannya dalam proses belajar mengajar. ${ }^{34}$

Proses pembelajaran harus mampu mewujudkan tujuantujuan berikut ;

a. Mengembangkan rasa tanggung jawab pada diri murid

b. Mengembangkan perasaan merdeka dan mandiri

c. Mengembangkan jiwa menghormati dan menghargai diri sendiri

d. Mengembangkan keinginan kuat untuk memberikan pertolongan pada orang lain dan menghormati perasaan mereka.

e. Mengembangkan kemampuan adaptasi dengan keadaan yang berubah-ubah dan situasi sulit.

${ }^{33}$ Tohirin, Psikologi Pembelajaran Pendidikan Agama Islam....,90.

${ }^{34}$ Zakiah Daradjat, Pembinaan Jiwa Mental (Cet.III ;Jakarta :Bulan Bintang, 1974), 19. 
f. Meningkatkan perasaan bahagia dan aman. ${ }^{35}$

Sedangkan faktor lain yang dapat menunjang kesadaran beragama yaitu :

a. Kepedulian kepala sekolah, guru-guru dan staf sekolah lainnya terhadap pelaksanaan pendidikan agama (penanaman nilai-nilai agama) di sekolah melalui pemberian contoh dalam bertutur kata, berprilaku dan berpakaian sesuai ajaran Islam. Juga guru-guru bidang studi umum menyisipkan nilai-nilai agama dalam mata pelajarannya.

b. Tersedianya sarana ibadah yang memadai dan memfungsikan secara optimal.

c. Penyelenggaraan kegiatan ekstrakurikuler kerohanian bagi para siswa dan ceramah-ceramah atau diskusi keagamaan yang rutin. ${ }^{36}$

\section{Lingkungan Masyarakat}

Situasi atau kondisi interaksi sosial dan sosial kultural yang secara potensial berpengaruh terhadap perkembangan kesadaran beragama individu. Dalam masyarakat anak berinteraksi dengan teman sebayanya. Hurlock mengemukakan bahwa aturan-aturan (kelompok bermain) memberikan pengaruh pada pandangan moral dan tingkah laku kelompoknya, kualitas perkembangan kesadaran anak sangat bergantung pada kualitas prilaku orang dewasa atau warga masyarakat. ${ }^{37}$ Kualitas pribadi orang dewasa yang kondusif bagi perkembangan kesadaran beragama anak adalah :

a. Taat melaksanakan kewajiban agama seperti ibadah ritual, menjalin persaudaraan, saling menolong dan bersikap jujur. Juga membentuk pengajian anak-anak dan membentuk Majelis Taklim

b. Menghindari diri dari sikap dan prilaku yang dilarang oleh agama. $^{38}$

\footnotetext{
${ }^{35}$ Makmun Mubayidh, 127.

${ }^{36}$ Syamsul Yusuf, loc. cit., Lihat pula A. Qodry Azizy, op. cit.,73-74.

${ }^{37}$ Hurlock, op. cit., 436.

${ }^{38}$ Syamsul Yusuf, op. cit., 189.
} 
Menurut analisis penulis, dapat dikatakan bahwa untuk membangun kecerdasan emosional dan spiritual maka segala belenggu yang dapat membutakan hati harus dihilangkan lalu menyeimbangkan dengan nilai-nilai keimanan lalu diaplikasikan dengan nilai-nilai keislaman. Di samping itu lingkungan juga sangat mendukung pertumbuhan tersebut. Ketidak efektifan satu lingkungan saja akan mengakibatkan tujuan yang akan dicapai tidak dapat berhasil dengan baik.

\section{Penutup}

Berdasarkan uraian di atas dapat di simpulkan beberapa hal antara lain; Pertama, konsep kecerdasan emosional menurut pendidikan Islam sebagaimana dikemukan para pakar pendidikan Islam cenderung dipahamai sebagai perwuju sikap-sikap terpuji dari kalbu dan akal yakni sikap bersahabat, kasih sayang, empati, takut berbuat salah, keimanan, dorongan moral, bekerjasama, beradaptasi, berkomunikasi dan penuh perhatian serta kepedulian terhadap sesama mahluk ciptaan Tuhan. Adapun ciri yang menandai kecerdasan emosional dalam pendidikan Islam terdapat pada pendidikan akhlak. Para pakar pendidikan Islam dengan berbagai ungkapan, pada umumnya sepakat bahwa tujuan pendidikan Islam adalah membina pribadi muslim yang sempurna dan beribadah kepada Allah swt. termasuk salah satunya adalah akhlak mulia. Al-Akhlāk al-karimah dalam Islam adalah hal yang berhubungan dengan kecakapan emosi dan spiritual seperti konsistensi (Istiqāmah), rendah hati (tawādu), berusaha keras (Tawākkal), ketulusan (Ikhlās), Totalitas (Käffah), Keseimbangan (tawāzun), integritas dan penyempurnaan (Ihsān). Kedua, strategi pendidikan Islam dalam menumbuhkan kecerdasan emosional menekankan domaian peranan komponen pendidikan yang mencakup lingkungan keluarga, lingkungan sekolah, dan lingkungan masyarakat sebagai basis utama pembentukan kecerdasan emosional anak dalam proses pendidikan.

\section{DAFTAR PUSTAKA}

Abdul Mujib dan Yusuf Mudzakkir, Ilmu Pendidikan Islam .Yogyakarta:Graha Ilmu, 2007 
Abdullah Nashih Ulwan, Tarbiyatu al-Awlad fi al-Islam. Beirut: Dar alSalam , 1978

Abu Hamid Muhammad al-Ghazali, Ihya Ulum al-Din, Jilid.III Beirut:Dar al-Fikr, 1989

Abuddin Nata, Manajemen Pendidikan, Bogor ; Kencana, 2003

Agustian, Ary Ginanjar. ESQ, The ESQ Way 165 I Ihsan 6 Rukun Iman dan 5 Rukun Islam Cet. II;Jakarta : Arga, 2001.

Ahmad Tafsir, Ilmu Pendidikan dalamPersfektif islam, Bandung:Remaja Rosda Karya, 1991

Ahyadi, Abdul Aziz. Psikologi Agama, Kepribadian Muslim Pancasila Cet.I ;Bandung :Sinar Baru, 1986.

Al- Tirmidzi, Sunan al-Tirmizi, Kitab al-Adahiy, Bab al-Azan Fī Uzūn alMaulud (Lebanon: Dar al-Fikr, $1414 \mathrm{H}$.

Ary Ginanjar Agustian, ESQ The ESQ Way 165. XX;Jakarta:Arga, 2005

Departemen Agama, al-Qur'an dan Terjemahnya. Jakarta:Cipta Adi Pustaka, 1971

Hurlock Elizabeth, Child Development (New York:Mc. Graw Hill Book Company Inc

Jalaluddin, Mempersiapkan Anak Saleh (Telaah Pendidikan terhadap Sunnah Rasulullah Saw), Jakarta:Raja Grafindo Persada, 2002.

M.Yaniyullah Delta Auliya, Melejitkan Hati dan Otak Menurut Petunjuk alQur'an dan Neurologi, Edisi I. Jakarta:Raja Grafindo Persada, 2005

Muhaimin, Ilmu Pendidikan Islam suatu Tinjauan Teoritis dan Praktis Berdasarkan Pendekatan Interdisipliner . Jakarta:Bumi Aksara, 2000

Syamsul Ma'arif, Revitalisasi Pendidikan Islam, Edisi I (Yogyakarta:Graha Ilmu, 2007

Tohirin, Psikologi Pembelajaran Pendidikan Agama Islam, Edisi I (Jakarta:Raja Garfindo Persada, 2006

Yasien Mohamed, Insan yang Suci,Konsep Fitrah dalam Islam; Bandung:Mizan, 1997

Zakiah Daradjat, Pembinaan Jiwa Mental ,Jakarta :Bulan Bintang, 1974.

Zakiah Daradjat, Pendidikan Islam dalam Keluarga dan Sekolah .Jakarta:Ruhama, 1995. 
Jurnal Ilmiah "Kreatif" Vol. 18 No. 1, Januari 2020 "Jurnal Studi Pemikiran Pendidikan Agama Islam"

$-46-$ 